\title{
Bidens meyeri (Asteraceae, Coreopsideae): a new critically endangered species from Rapa,Austral Islands
}

\author{
Vicki A. Funk', Kenneth R. Wood ${ }^{2}$ \\ I US National Herbarium, Department of Botany, Smithsonian Institution, PO Box 37012, Washington, DC \\ 20013-7012, USA 2 National Tropical Botanical Garden, 3530 Papalina Road, Kalaheo, HI 96741, USA \\ Corresponding author: Vicki A. Funk (funkv@si.edu)
}

Academic editor:AlexanderSennikov | Received 8August 2014| Accepted 16September 2014| Published 13October 2014

Citation: Funk VA, Wood KR (2014) Bidens meyeri (Asteraceae, Coreopsideae): a new critically endangered species from Rapa, Austral Islands. PhytoKeys 42: 39-47. doi: 10.3897/phytokeys.42.8408

\begin{abstract}
Bidens meyeri (Asteraceae/Compositae) is described and illustrated from Rapa, Austral Islands, (French Polynesia). This new species is presumed to be most closely related to Bidens saint-johniana from nearby Marotiri Island. Bidens meyeri may be distinguished from B. saint-johniana based on the length of the peduncle $(3 \mathrm{~cm}$ versus $10 \mathrm{~cm}$ ), apex of the inner involucral bracts (glabrous vs. puberulent), smaller leaves $(2.0-2.3 \mathrm{~cm}$ vs. $5-6 \mathrm{~cm})$, and the general smaller size of the new species. Known from less than $50 \mathrm{in}-$ dividuals and restricted to one remote location, Bidens meyeri falls into the IUCN Critically Endangered (CR) category. The new species is named in honor of Dr. Jean-Yves Meyer, Délégation à la Recherche, Polynésie Française,
\end{abstract}

\section{Keywords}

Asteraceae, Austral Islands, Bidens, Coreopsideae, Compositae, conservation, endemic, French Polynesia, IUCN Red List Category, Oceania, Rapa Iti.

\section{Introduction}

The Austral Islands are situated in the Southern Pacific and are part of French Polynesia. The Archipelago lies south of the Society Islands and consists of seven main islands of volcanic origin, and one atoll (Maria). The high islands include Rurutu, Tubuai, Rimatara, and Ra' ivavae as well as Rapa $\left(27^{\circ} 36^{\prime} 00^{\prime \prime} S ; 144^{\circ} 17^{\prime} 00^{\prime \prime W}\right)$, the second largest island (i.e., $40 \mathrm{~km}^{2}$ ). Rapa is about 5 million years old and it is very rugged, char- 
acterized by steep central ridges, mist shrouded spires, and towering black basalt seacliffs (Clarke 1971, Clouard and Bonneville 2005, Appelhans et al. 2014). The highest peak, Mont Perau (ca. $650 \mathrm{~m}$ ), is covered by a small area of cloud forest (Meyer 2010).

Rapa is a high volcanic island and its climate is considered to be wet subtropical / subtemperate with a mean annual temperature of $20.6^{\circ} \mathrm{C}$, a minimum at $8.5^{\circ} \mathrm{C}$, and mean annual rainfall of $2500 \mathrm{~mm}$ at sea level (Barsczus 1980; Meyer 2011). Levels of endemism have been reported as very high among certain organisms, such as weevils (Paulay 1985). Area, altitude, and nearest land mass all have an effect on the evolution of the biota in these islands with Rapa being the second largest, highest, and most distant of all of the Austral islands. It is nearly $1200 \mathrm{~km}$ southeast of Tahiti, $3700 \mathrm{~km}$ northeast of the north island of New Zealand, and $8500 \mathrm{~km}$ southwest of the Baja Peninsula in Mexico. Threats to the biodiversity are primarily a result of burning, grazing (in particular goats and cattle), and invasive alien plant species.

Rapa has 238 native taxa of flowering plants and ferns including infraspecific categories, 85 of these are endemic to the Austral islands (35\%), 73 of these are single island endemic taxa (30\%) including this new species of Bidens. Considering only flowering plants, Rapa has 152 native flowering plant taxa, of these 65 (43\%) are endemic to the Austral islands and 53 (35\%) are endemic to Rapa (Meyer 2002, Wood 2002, Wood pers. com.). Two island endemic genera in the Compositae have been reported: Apostates N.S. Lander in the Madieae tribe, part of the Heliantheae Alliance, and Pacifigeron G.L. Nesom in the Astereae. Also, there are endemic Compositae species on Rapa that belong to two 'endemic to Polynesia' genera, namely Fitchia Hook. f. and Oparanthus Sherff both in the Coreopsideae tribe which is also part of the Heliantheae Alliance (Florence 1997, Shannon and Wagner 1997, Wagner and Lorence 2014).

In March - April 2002, during an expedition supported by the National Geographic Society, a group of scientists from the New York Botanical Garden (NYBG); the Délégation à la Recherche, Polynésie Française; and the National Tropical Botanical Garden (NTBG), Kaua i, Hawai' i, conducted a botanical survey of the island of Rapa. They expected to stay there for a month. In fact, because of a logistic problem that delayed the supply ship (their means of transportation), several of them stayed for two months. During this Rapa expedition a number of very interesting taxa were discovered, one of which was a Bidens that could not be placed into any existing species (Fig. 1; Meyer 2002, Wood 2010).

Describing this taxon was unusually difficult because of the scant material (Fig. $2 \mathrm{a}, \mathrm{b})$. Other samples were collected during the expedition but are inaccessible. The collector of the holotype specimen gathered several isotypes that would have been sufficient, however, all except the small one he retained (the type) have evidently been misplaced and with the untimely death of the expeditions team leader, Dr. Timothy Motley (NY followed by ODU), the specimens have not been available for study. On a subsequent expedition in December of 2002, an additional collection was made by Jean-Yves Meyer close to the original location (Meyer 2315; Fig. 1). Meyer's collection was sent to the Paris herbarium (P) but cannot now be located (Meyer, pers. com.). After waiting for over ten years we have decided to go forward with the description of this new taxon as it is being included in a forthcoming molecular analysis and needs to 

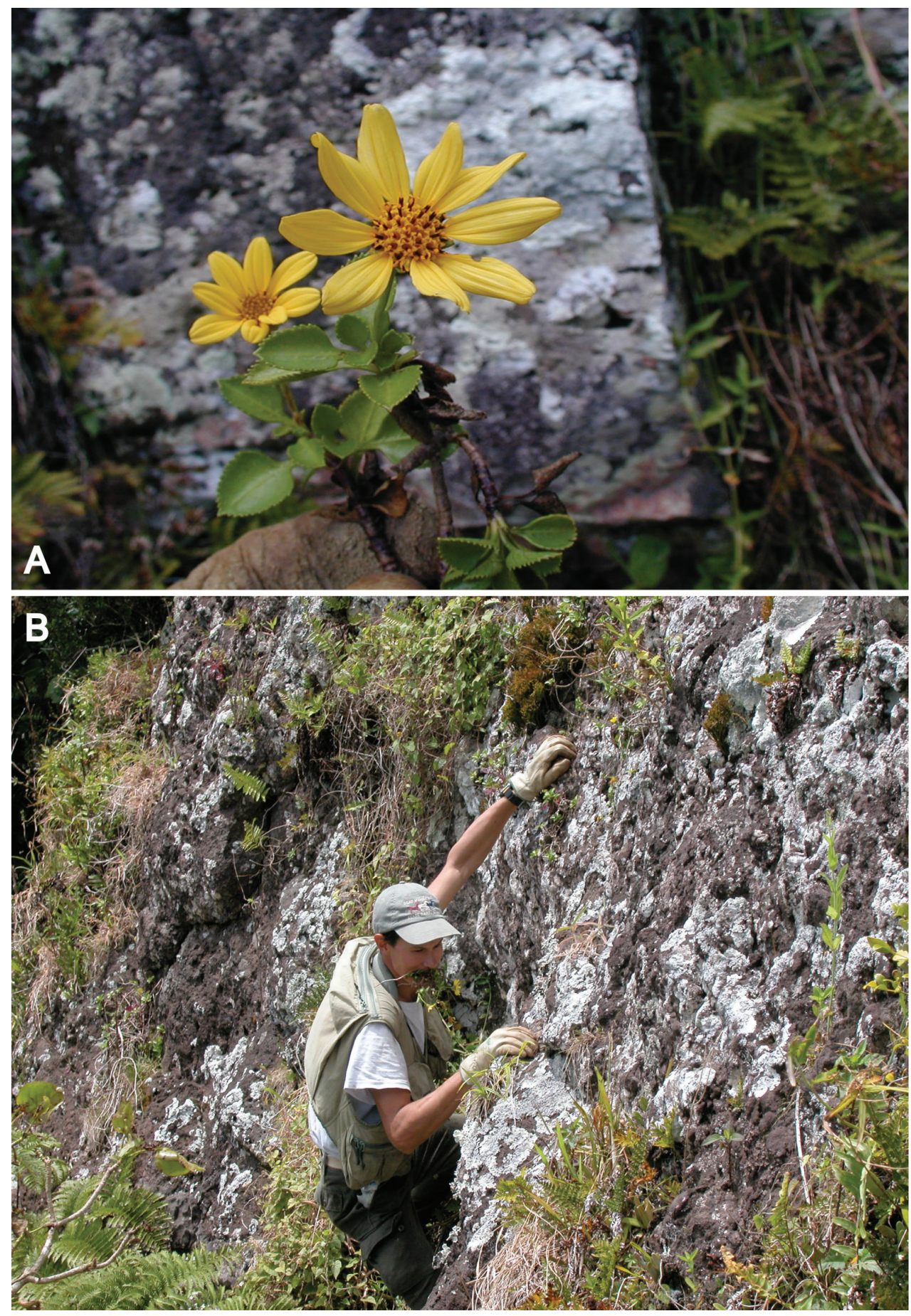

Figure I. Photos of Bidens meyeri: A Close up of a flowering plant, note the gloved finger holding the plant B J-Y Meyer climbing with Bidens in his teeth, note yellow flowering plant on the cliff face just above his left hand. [Photo credits: A by J-Y Meyer; B by R Englund; both taken 16 Dec 2002]. 
be recognized for future conservation efforts. The leaf sample for the molecular analysis was taken from the holotype, prior to its designation as a holotype, with permission from the National Tropical Botanical Garden.

\section{Taxonomic treatment}

Bidens meyeri V.A. Funk \& K.R. Wood, sp. nov. urn:Isid:ipni.org:names:77142603-1

Fig. 2A-C

Type. Austral Islands. Rapa, cliffs above Maitua, rappel below Maungaoa, 3 Apr 2002, K.R. Wood \& Heimoana Faraire 9515 (holotype: PTBG-067702!); 27³7'30"S; $144^{\circ} 20^{\prime} 20^{\prime \prime W}$.

Description. Sub-shrub with 3-4 branches growing on cliff faces, ca. $25 \mathrm{~cm}$ tall, small side branches ca. $8 \mathrm{~cm}$ tall; stems brown, glabrous, lower portion smooth, upper portion striated, ca. $1 \mathrm{~mm}$ wide (when dry), glabrous, older nodes with the remains of leaf bases. Leaves opposite, simple, somewhat fleshy, glabrous, without true petioles but looking petiolate because of narrowed blade bases, $2.1-2.3 \mathrm{~cm}$ long; broad part of leaf ovate, glossy green above, dull green below, $1.1-1.5 \mathrm{~cm}$ long $\times 1.0-1.2 \mathrm{~cm}$ wide; margins of broad part of leaf dentate with teeth curved toward apex and with mucronate tips, 6-9 teeth per side; apex mucronate or apiculate; venation pinnate usually with one lateral vein for each tooth; narrow portion of leaf $\mathrm{ca} .1 \mathrm{~cm}$ long decurrent with leaf bases wrapping around stem and nearly touching one another. Heads solitary, $-1 \mathrm{~cm}$ in diameter (excluding rays), peduncle $3 \mathrm{~cm}$ long, glabrous with prominent ribs (when dried); involucral bracts in 2-3 rows, outer two rows bright green, purple tipped in some, slightly fleshy, glabrous with 3 prominent veins (when dried), arched outward, ca. $5 \mathrm{~mm} \times 1.3 \mathrm{~mm}$ (at the broadest point near the apex), apex rounded with a small acute tip; innermost row (may also be outer row of receptacular bracts) lanceolate, brownish with lighter hyaline margins, glabrous, $5.5 \mathrm{~mm} \times 1.1 \mathrm{~mm}$ (at widest point near the base). Ray flowers yellow with many veins, 8-9 per head, sterile, ca. 9 $\mathrm{mm}$ long (including $2 \mathrm{~mm}$ tube) $\times 1.5-2.0 \mathrm{~mm}$ wide; disk flowers ca. 30-40, perfect; corollas yellow, glabrous; anther thecae dark, pollen yellow; style branches yellow. Pappus of 2 very short irregular awns with scattered hairs but without barbs. Achenes immature but apparently dark colored and glabrous, at least near the apex.

Additional collection. Austral Islands: Rapa, Tevaitau on cliff, only two plants seen, 272 m, on bare rock, 16 Dec 2002, J.-Y. Meyer 2315 (Specimen hopefully at P). Fig. 1.

Distribution and ecology. The type of Bidens meyeri was discovered during a rappel utilizing ropes and climbing-saddle around the windswept mesic cliffs above Maitua, Rapa, French Polynesia. The holotype location is the only population of any size; the second collecting site had only two individuals. The type locality can be described as a windswept mesic cliff habitat with small ledges and pockets of granular 


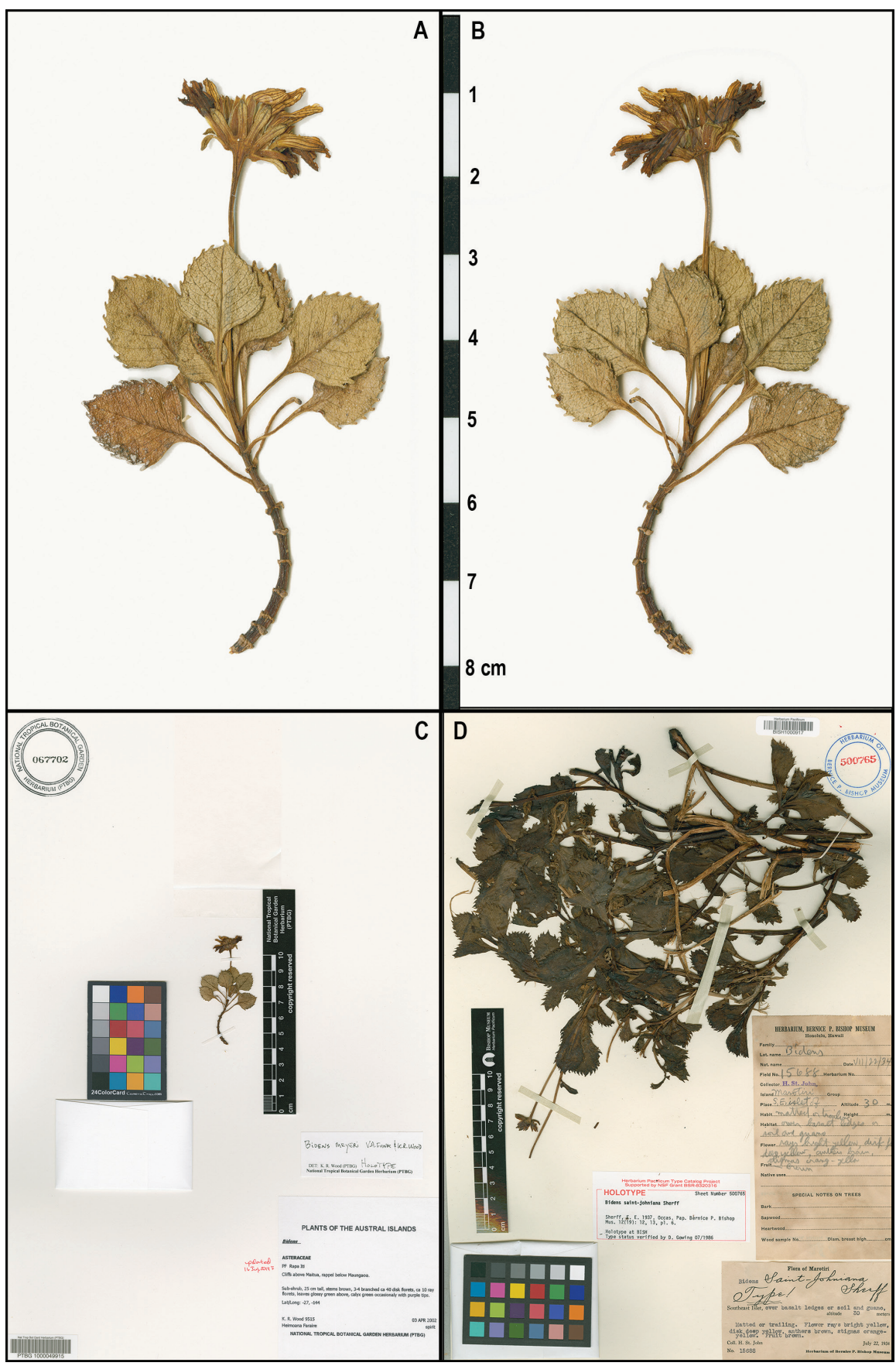

Figure 2. Photos of Bidens type specimens: A-C Bidens meyeri holotype (PTBG): A-B Specimen before mounting $\mathbf{A}$ Side with the involucral bracts and (mostly) upper surface of the leaves showing $\mathbf{B}$ Side with the flowers and (mostly) the undersurface of leaves showing $\mathbf{C}$ Holotype of Bidens meyeri, housed at PTBG D Holotype of Bidens saint-johniana, housed at BISH. [Photo credits: A-C by Jesse Adams, PTBG; D sent by BISH]. 
soil, bordered by steep slopes interspersed with herbs and low-statured native forest and shrubland. The aspect is northeast with a $70 \%$ open canopy for exposure to sun. Associated tree species include Oparanthus coriaceus (F. Br.) Sherff, O. rapensis (F. Br.) Sherff, Corokia collenettei Riley, Fitchia rapense F. Br., Metrosideros collina (J.R. Forst. \& G. Forst.) A. Gray var. villosa (L.) A. Gray, Apetahia margaretae (F. Br.) Wimmer, and Sophora rapaensis H. St. John. Shrubs, vines, and herbs include Plantago rupicola Pilg., Dianella intermedia Endl. var. punctata F. Br., Veronica rapensis F. Br., Kadua rapensis F. Br., Alyxia stellata (J.R. Forst. \& G. Forst.) Roem. \& Schult., Dichelachne crinita (L. f.) Hook. f., and some Freycinetia arborea Gaudich. Associated ferns include Blechnum attenuatum (Sw.) Mett., Blechnum vulcanicum (Blume) Kuhn var. rapense E.D. Br., Sphaeropteris medullaris (G. Forst.) Bernh., Alsophila stokesii (E.D. Br.) R.M. Tryon, Polystichum rapense E.D. Br., Belvisia dura (Copel.) Copel., Thelypteris margaretae (E.D. Br.) Ching, Davallia solida (G. Forst.) Sw., Selaginella arbuscula (Kaulf.) Spring, Nephrolepis exaltata (L.) Schott, and Pteris comans G. Forst (Wood 2002, pers. com.). Meyer 2315 was collected at a site with Pyrrosia serpens (G. Forst.) Ching, Peperomia sp., Verbena litoralis Kunth, Commelina diffusa Burm. f, Davallia solida (G. Forst.) Sw. and Psilotum nudum (L.) P. Beauv (pers. com.).

Etymology. The new species is named in honor of Dr. Jean-Yves Meyer, friend and conservation biologist at the Délégation à la Recherche, Polynésie Française, in recognition of his research of this species and his efforts in exploring and conserving the unique biota of Rapa (e.g., Meyer 2011).

\section{Discussion}

The only other native species of Bidens from the Austral Islands is B. saint-johniana Sherff (1937) found on Marotiri, a group of small rocky islets located ca. $80 \mathrm{~km}$ southeast of Rapa. Marotiri has been surveyed only twice by botanists: St. John and Forges. Bidens saint-johniana was first collected at the Southeast Islet, 22 July 1934, by Harold St. John (Fosberg 1972; St. John 1982) and his assistant at the time, Ray Fosberg (St. John 15683; holotype: BISH; isotype F, http://plants.jstor.org/specimen/ f0075334f?history=true; images of both were examined; Fig. 2D), and again in 1979 by B. Richer de Forges (Nicolas Hallé 6860, P; Hallé 1980). Bidens saint-johniana is a much more robust plant than $B$. meyeri, its leaves are larger (total length $5-6 \mathrm{~cm}$, width at the widest part $3.5-4.0 \mathrm{~cm})$ and peduncle longer $(10 \mathrm{~cm}$ vs. $3 \mathrm{~cm})$, and the apex of the inner involucral bracts is puberulent (vs. glabrous). Based on the images of the holotype (BISH; Fig. 2D) and isotype (F) the leaves are not thickened and the teeth are larger and not as curved and do not have a mucronate tip. Finally the length of the side branches was $14-15 \mathrm{~cm}$ as opposed to those of $B$. meyeri which are less than $8 \mathrm{~cm}$.

When the new species was run through the key in the Bidens treatment written by Welsh (1998) covering the Society Islands, it did not key out to anything remotely similar and it did not fit any of the descriptions. It does, however, have 
some superficial resemblance to B. molokaiensis Sherff and B. maniensis Sherff from Hawaii, as Sherff (1937) observed.

Rapa's flora is usually mentioned as being closely allied to that of New Zealand and Australia. However, after evaluating the results of numerous exceptions, some botanists (e.g., van Balgooy 1971) consider Rapa to be an 'anomalous district' in the SE Polynesian Province, and the high levels of endemic biological diversity in both the flora and fauna still puzzle many scientists because of the island's relatively small size. There are 53 flowering plant species (35\%) that are single island endemics to Rapa, including three endemic plant genera, namely Apostates (Asteraceae: Bahieae), Pacifigeron (Asteraceae: Astereae) and Metatrophis F. Br. (Urticaceae). The new species is clearly related to the Pacific Bidens radiation (Hawaii \& French Polynesia) rather than taxa found on Rapa's neighbors to the South.

\section{Conservation status}

Utilizing the World Conservation Union (IUCN) criteria for endangerment (IUCN 2001), we find that Bidens meyeri easily falls into the Critically Endangered (CR) category, and faces a very high risk of extinction in the wild. The IUCN alphanumeric summary of our evaluation of criteria and subcriteria is: B1ab(v); B2a, B2b(i-iii); D. These criteria are defined as: B1, extent of occurrence less than $100 \mathrm{~km}^{2}$; B1a, known to exist at only a single location; $\mathrm{B} 1 \mathrm{~b}(\mathrm{v})$ continuing decline inferred in number of mature individuals; B2, total area of occupancy less than $10 \mathrm{~km}^{2}$; B2a, one population known; $\mathrm{B} 2 \mathrm{~b}$ (i-iii), habitat continuing decline inferred; $\mathrm{D}$, population estimated to number fewer than 50 individuals. Threats to $B$. meyeri include possible fires, habitat degradation and destruction by feral goats (Capra hircus L.), along with competition with nonnative plant taxa especially Psidium cattleianum Sabine and, of course, climate change.

\section{Acknowledgements}

We would like to thank Jean-Yves Meyer and Priscille Frogier of the Délégation à la Recherche de la Polynésie Française, for their support of research in French Polynesia; Staff at the National Tropical Botanical Garden for continued support and assistance at the PTBG herbarium, especially Tim Flynn, Dave Lorence, and Jesse Adams; Timothy J. Motley $\dagger$ (NYBG at the time of the expedition), organizer of the 2002 Rapa Expedition, and the National Geographic Society for partial funding; Steve Perlman (NTBG), Jean-Francois Butaud (Service du Développement Rural, Tahiti), Cerdan and Heimoana Faraire (Rapa) for field assistance. We also thank Jean-Yves Meyer, Ron Englund, and Jessie Adams for the photographs, Alice Tangerini (US) for helping assemble Fig. 2, Shelly James (BISH) who kindly made available a high-resolution image of the holotype of B. saint-johniana, and the herbarium of the Field Museum (F), and JSTOR Global Plants Initiative for putting the image of the isotype online. 


\section{References}

Appelhans MS, Wagner WL, Wood KR (2014) Melicope balgooyi Appelhans, W.L.Wagner \& K.R. Wood, a new species and new record in Melicope section Melicope (Rutaceae) for the Austral Islands. Phytokeys 39: 77-86. doi: 10.3897/phytokeys.39.7691

Barsczus HG (1980). Les îles Australes (Polynésie francaise) et la théorie des points chauds. Notes et Documents de Géophysique. ORSTOM, Papeete, Tahiti, 27 pp.

Clarke JFG (1971) The Lepidoptera of Rapa Island. Smithsonian Contributions to Zoology 56: 1-282. http://www.sil.si.edu/smithsoniancontributions/zoology/pdf_hi/sctz-0056.pdf Clouard V, Bonneville A (2005) Ages of seamounts, islands and plateaus on the Pacific Plate. In: Foulger GR, Natland JH, Presnall DC, Anderson DL (Eds) Plates, plumes, and paradigms. Geological Society of America, Special Paper 388, 71-90. doi: 10.1130/0-8137$2388-4.71$

Florence J (1997) Flore de la Polynésie francaise. Volume 1. Collection Faune et Flore Tropicales. Editions de l'ORSTOM, Paris, 34 pp.

Fosberg R (1972) Morotiri (Bass Rocks) Austral Islands. Atoll Research Bulletin 162: 9-10. http://www.sil.si.edu/digitalcollections/atollresearchbulletin/issues/00258.pdf

Hallé N (1980) Les Orchidées de Tubuaï (archipel des Australes, Sud Polynésie): Suivies d'un catalogue des Plantes à fleurs et Fougères des îles Australes. Cahiers de l'Indo-Pacifique. 2(3): 69-130. [catalogue 85-130]

IUCN (2001) IUCN Red List Categories and Criteria Version 3.1. Prepared by the IUCN Criteria Review Working Group. IUCN, Cambridge. http://www.iucnredlist.org/technicaldocuments/categories-and-criteria/2001-categories-criteria

Meyer J-Y (2002) Rapport de mission d'exploration botanique à Tubuai et Rapa (Australes) du 13 mars au 5 avril 2002. Délégation à la Recherche de la Polynésie française, Papeete, 26 pp. http://www.li-an.fr/jyves/Meyer_2002_Rapport_mission_Tubuai_\&_Rapa.pdf

Meyer J-Y (2010) Montane cloud forests in remote islands of Oceania: the example of French Polynesia (South Pacific Ocean). In: Bruijnzeel LA, Scatena FN, Hamilton LS (Eds) Tropical Montane Cloud Forests: Science for Conservation and Management. Cambridge University Press, Cambridge, 121-129.

Meyer J-Y (2011) Rapa, îles Australes: guide de la flore indigène et endémique. Direction de l'Environnement, Délégation à la Recherche: STPmultipress, Papeete.

St. John H (1982) Marotiri rock pinnacles in the South Pacific. Occasional Papers of the Bernice P. Bishop Museum 25(4): 1-4. http://hbs.bishopmuseum.org/pubs-online/pdf/op25-4.pdf Shannon RK, Wagner WL (1997) Oparanthus (Asteraceae, subtribe Coreopsidinae) revisited. Allertonia 7: 273-295. https://repository.si.edu/bitstream/handle/10088/20991/bot_ Shannon_and_Wagner_1997_Oparanthus.pdf?sequence=1

Sherff EE (1937) Some Compositae of southeastern Polynesia (Bidens, Coreopsis, Cosmos, and Oparanthus). Occasional Papers of the Bernice P. Bishop Museum 12(19): 1-19. http://hbs.bishopmuseum.org/pubs-online/pdf/op12-19.pdf

van Balgooy MMJ (1971) Plant-geographical analysis of the pacific. Blumea Supplement 6: $1-122$. 
Wagner WL, Lorence DH (2011) Two new Marquesan species of the southeastern Polynesian genus Oparanthus (Asteraceae, Coreopsidinae). PhytoKeys 4: 139-148. doi: 10.3897/phytokeys.4.1603

Welsh SL (1998) Flora Societensis: a summary revision of the flowering plants of the Society Islands. Mehetia, Tahiti, Moorea, Tetiaroa (iles du vent); Huahine, Raiatea, Tahaa, Bora Bora, Tupai, Maupiti, and Mopelia (iles sous le vent). Orem, Utah: E.P.S. Inc., 420 pp.

Wood KR (2002) Further Notes on Rapa, Austral Islands, French Polynesia. Garden Chronicles, National Tropical Botanical Garden, Kalaheo, Hawai i, 3(2): 13-15.

Wood KR (2010) Tales from the Field: Following an inner voice in search of Rapa's rare Apostates. The Bulletin, National Tropical Botanical Garden, Kalaheo, Hawai i, 27(2): 11-17. http://ntbg.org/sharing/magazine.php\#804 